\title{
IMMIGRANTS AND INTERDEPENDENCE: HOW THE COVID-19 PANDEMIC EXPOSES THE FOLLY OF THE NEW PUBLIC CHARGE RULE
}

\author{
Medha D. Makhlouf \& Jasmine Sandhu
}

\begin{abstract}
On February 24, 2020, just as the Trump Administration began taking significant action to prepare for an outbreak of COVID-19 in the United States, it also began implementing its new public charge rule. Public charge is an immigration law that restricts the admission of certain noncitizens based on the likelihood that they will become dependent on the government for support. A major effect of the new rule is to chill noncitizens from enrolling in public benefits, including Medicaid, out of fear of negative immigration consequences. These chilling effects have persisted during the pandemic. When noncitizens are afraid to (1) seek treatment or testing for COVID-19 or (2) access public benefits in order to comply with stay-athome guidance, it impedes efforts to slow the spread of COVID-19, contributing to the strain on the health care system. This Essay describes how the pandemic has exposed the folly of the public charge rule: Discouraging noncitizens from accessing public benefits to support their health and wellbeing is, and always has been, unwise from a public health perspective. The pandemic merely magnifies the negative consequences of this policy.

This Essay contributes to scholarly conversations about how immigration law and policy have framed the United States' response to the COVID-19 pandemic. Specifically, it provides an in-depth analysis of the negative public health consequences of the new public charge rule during the pandemic.
\end{abstract}

AuTHORS - Medha D. Makhlouf is an Assistant Professor and Director of the Medical-Legal Partnership Clinic at Penn State Dickinson Law, and an Assistant Professor in the Department of Public Health Sciences at Penn State College of Medicine. Jasmine Sandhu received her J.D. from Penn State Dickinson Law, where she worked as a Student Attorney at the Medical-Legal Partnership Clinic. She has a B.S. in Community and Regional Development from University of California, Davis. The authors are grateful to Christian Sweger for his excellent research assistance and to the staff of the Northwestern University Law Review for their incisive editing. 
INTRODUCTION 147

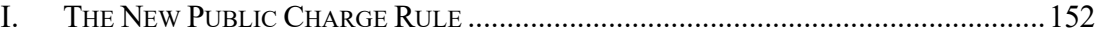

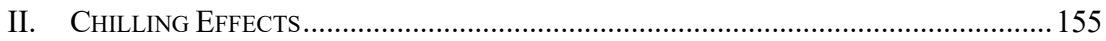

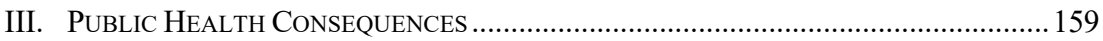

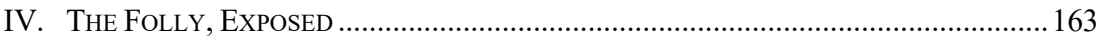

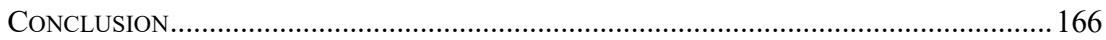

\section{INTRODUCTION}

The COVID-19 pandemic is an unprecedented public health crisis in the modern era, and the United States has taken unprecedented measures to address it. ${ }^{1}$ Government officials have required or encouraged the public to practice social distancing ${ }^{2}$ and have ordered the closure of schools, workplaces, restaurants, and other "nonessential" businesses. ${ }^{3}$ The spread of COVID-19 and the extraordinary measures to combat it have brought to light the enduring failures of our human ecosystem, ${ }^{4}$ leaving people with the

\footnotetext{
${ }^{1}$ See, e.g., Joan Stephenson, Coronavirus Outbreak-An Evolving Global Health Emergency, JAMA HEALTH F. (Feb. 4, 2020), https://jamanetwork.com/channels/health-forum/fullarticle/2760671 [https://perma.cc/SE6C-WS9B] (explaining that, although the action of mandatory quarantine orders is an unprecedented action and one that has not occurred in the last fifty years, it is necessary in light of an unprecedented public health threat).

2 Social distancing, also referred to as "physical distancing," involves limiting contact with people outside of one's household in order to reduce potential exposure to the virus. Social Distancing, CTRS. FOR DiSEASE CONTROL \& PREVENTION (July 15, 2020), https://www.cdc.gov/coronavirus/2019ncov/prevent-getting-sick/social-distancing.html [https://perma.cc/84WW-F5HA].

3 See, e.g., Erin Schumaker, Here Are the States that Have Shut Down Nonessential Businesses, ABC News (Apr. 3, 2020, 6:58 PM), https://abcnews.go.com/Health/states-shut-essential-businessesmap/story?id=69770806 [https://perma.cc/KZR6-F7KS]; Russell M. Viner, Simon J. Russell, Helen Croker, Jessica Packer, Joseph Ward, Claire Stansfield, Oliver Mytton, Chris Bonell \& Robert Booy, School Closure and Management Practices During Coronavirus Outbreaks Including COVID-19: A Rapid Systematic Review, 4 LANCET Child AdolesCent HeAlth 397, 397 (2020). As cities and states began to close down nonessential businesses, professional sports leagues canceled or postponed seasons. Chas Danner, Most U.S. Sports Leagues Suspend Play Due to COVID-19, INTELLIGENCER (Mar. 12, 2020), https://nymag.com/intelligencer/2020/03/coronavirus-us-sports-leagues-ncaa-mlb-nba-suspendseasons-updates.html [https://perma.cc/HGZ2-XK6N].

4 See Emily A. Benfer \& Lindsay F. Wiley, Health Justice Strategies to Combat COVID-19: Protecting Vulnerable Communities During a Pandemic, Health AfFs. Blog (Mar. 19, 2020), https://www.healthaffairs.org/do/10.1377/hblog20200319.757883/full/ [https://perma.cc/8L47-97Q3]; Charles M. Blow, Opinion, Social Distancing Is a Privilege, N.Y. TIMES (Apr. 5, 2020), https://www.nytimes.com/2020/04/05/opinion/coronavirus-social-distancing.html [https://perma.cc/8H ZY-EQ6F]. These failures are often described as "holes in the safety net." See, e.g., Jason DeParle, The Safety Net Got a Quick Patch. What Happens After the Coronavirus?, N.Y. TIMES (Apr. 2, 2020), https://www.nytimes.com/2020/03/31/us/politics/coronavirus-us-benefits.html [https://perma.cc/JQB5T5VM]. We choose to refer to "the human ecosystem" rather than "the safety net" because the latter is a value-laden term that scholars and the media use to mean different things. Matthew B. Lawrence, Against
} 
fewest resources at heightened risk of acquiring (and spreading) the virus. There is growing recognition that in order to combat the spread of COVID19 , supplementing the income of people living in or near poverty is as necessary as mandating social distancing. ${ }^{5}$ In late March 2020, Congress passed emergency legislation that expanded and enhanced existing meanstested public benefit programs in order to ensure that people can follow social distancing guidelines, self-isolate if they have symptoms or are exposed to someone with symptoms, and obtain appropriate medical treatment such as telehealth screening and COVID-19 testing. ${ }^{6}$ As the pandemic emergency continues into the fall of 2020, Congressmembers are engaged in protracted negotiations over legislation authorizing additional financial relief. ${ }^{7}$ In August, the White House issued four executive orders extending pandemic-related financial relief. ${ }^{8}$

One vulnerable population that faces unique and disproportionate risks in this pandemic is noncitizens. ${ }^{9}$ Like many U.S. citizens, noncitizens work

the "Safety Net," 72 FLA. L. REV. 49, 65 (2020). "Human ecosystem" is a term used in public health scholarship that encompasses "the laws, institutions, behaviors, and environmental factors that through their interaction affect human health, activity, and the propagation of society." Id. at 70 .

${ }^{5}$ See Benfer \& Wiley, supra note 4 (explaining how "immediate legal, social, and financial protections" are needed to support social distancing and combat COVID-19).

${ }^{6}$ Families First Coronavirus Response Act, Pub. L. No. 116-127, 134 Stat. 178 (2020); Coronavirus Aid, Relief, and Economic Security (CARES) Act, Pub. L. No. 116-136, 134 Stat. 281 (2020).

7 See, e.g., Catie Edmondson, A Bipartisan Group of Lawmakers Urged the House to Remain in Washington Until a Pandemic Relief Bill Is Passed, N.Y. TIMES (Sept. 23, 2020), https://www.nytimes.com/live/2020/09/22/us/trump-vs-biden\#a-bipartisan-group-of-lawmakers-urgedthe-house-to-remain-in-washington-until-a-pandemic-relief-bill-is-passed [https://perma.cc/4TNNQR4D].

${ }^{8}$ See, e.g., Exec. Order No. 13,945, 85 Fed. Reg. 49,935 (Aug. 8, 2020); Memorandum on Continued Student Loan Payment Relief During the COVID-19 Pandemic, 2020 DAILY COMP. PRES. DoC. (Aug. 8, 2020); Memorandum on Authorizing the Other Needs Assistance Program for Major Disaster Declarations Related to Coronavirus Disease 2019, 2020 DAILY COMP. PRES. Doc. (Aug. 8, 2020); Memorandum on Deferring Payroll Tax Obligations in Light of the Ongoing COVID-19 Disaster, 2020 DAILY COMP. PRES. Doc. (Aug. 8, 2020).

9 See, e.g., Muzaffar Chishti \& Jessica Bolter, Vulnerable to COVID-19 and in Frontline Jobs, Immigrants Are Mostly Shut Out of U.S. Relief, MigRATION POL'Y InST. (Apr. 24, 2020), https://www.migrationpolicy.org/article/covid19-immigrants-shut-out-federal-relief [https://perma.cc/ 79DM-FT6J]. The disproportionate burden of COVID-19 infection and mortality on underrepresented minorities, particularly Black and Hispanic people, is well documented and attributable in great part to adverse social and structural determinants of health. See, e.g., Clyde W. Yancy, COVID-19 and African Americans, 323 JAMA 1891, 1891 (2020); Sunita Sohrabji, Asian Americans Have Disproportionately High Mortality Rate from COVID-19 in California, EthNiC Media Servs. (May 15, 2020), https://ethnicmediaservices.org/covid-19/asian-americans-have-disproportionately-high-mortality-ratefrom-covid-19-in-california/ [https://perma.cc/2BVU-ED3V]. Because most low-income noncitizens are people of color, noncitizen status represents a separate but sometimes overlapping dimension of vulnerability for this population. See, e.g., Jynnah Radford, Key Findings About U.S. Immigrants, PEw RSCH. CTR. (June 17, 2019), https://www.pewresearch.org/fact-tank/2019/06/17/key-findings-about-u-s- 
in low-wage positions that are considered essential and in which close contact with other people is unavoidable. ${ }^{10}$ These positions include home health aides, caregivers for children and the elderly, farmworkers, and warehouse and factory employees. ${ }^{11}$ Workers in these industries face a higher risk of exposure to the virus. ${ }^{12}$ Alongside citizens, noncitizens have also lost income due to reductions in hours and layoffs in the restaurant and retail sectors. ${ }^{13}$ Unlike U.S. citizens, however, noncitizens who are eligible for publicly funded health care and other benefits face a unique risk of accessing them: denial of immigration benefits.

Public charge is an immigration law that restricts the admission of noncitizens based on the likelihood that they will become dependent on the U.S. government for support. ${ }^{14}$ The public charge statute has always been a part of U.S. immigration law. ${ }^{15}$ Historically, the government rarely rejected applicants on public charge grounds. ${ }^{16}$ However, in August 2019, the U.S.

immigrants/ [https://perma.cc/LZF6-55PZ] (noting that Mexico, China, and India are top birthplaces for immigrants in the U.S.).

${ }^{10}$ See Chishti \& Bolter, supra note 9; Yancy, supra note 9.

${ }^{11}$ See Chishti \& Bolter, supra note 9; Miriam Jordan, Farmworkers, Mostly Undocumented, Become 'Essential' During Pandemic, N.Y. TIMES (Apr. 10, 2020), https://www.nytimes.com/2020/04/02/ us/coronavirus-undocumented-immigrant-farmworkers-agriculture.html [https://perma.cc/TLG6-DRSR] (noting "close working conditions in fields and [food] packing facilities").

12 See Chishti \& Bolter, supra note 9 (noting that "meatpacking plants, which often employ large numbers of immigrants and refugees, have become centers of coronavirus outbreaks"); Lazaro Gamio, The Workers Who Face the Greatest Coronavirus Risk, N.Y. TiMES (Mar. 15, 2020), https://www.nytimes.com/interactive/2020/03/15/business/economy/coronavirus-worker-risk.html [https://perma.cc/N36K-LBK2] (describing personal care aides and home health aides who work with the elderly; childcare workers; meat, poultry, and fish cutters and trimmers among the low-wage workers who face the greatest risk of infection); Agriculture Workers and Employers, CTRS. FOR DISEASE CONTROL \& PREVENTION (June 11, 2020), https://www.cdc.gov/coronavirus/2019ncov/community/guidance-agricultural-workers.html [https://perma.cc/TRW9-K5RS] (describing how close contact among farmworkers due to their occupational duties may put them at a higher risk of infection).

13 See Chishti \& Bolter, supra note 9.

14 Immigration and Nationality Act § 212(a)(4), 8 U.S.C. § 1182(a)(4); see Medha D. Makhlouf, The Public Charge Rule as Public Health Policy, 16 InD. HeAlth L. Rev. 177, 179-89 (2019) (summarizing the development of public charge policy); see also infra text accompanying notes 31-33 (explaining that under the prior interpretation of the statute, a person would be deemed a public charge only if they were likely to become totally dependent on the government for support). Prototypical public charges are nursing home residents and disabled recipients of cash assistance from the Supplemental Security Income program. See Leo M. Alpert, The Alien and the Public Charge Clauses, 49 YALE L.J. 18, 22 (1939) (describing residence in charitable institutions and "welfare relief" as the principal types of public assistance considered in public charge determinations).

15 Makhlouf supra note 14, at 179 (citing Act of Aug. 3, 1882, ch. 376, § 2, 22 Stat. 214).

16 See Adam Liptak, Supreme Court Allows Trump's Wealth Test for Green Cards, N.Y. TIMES (Jan. 27, 2020), https://www.nytimes.com/2020/01/27/us/supreme-court-trump-green-cards.html [https://perma.cc/AZ7U-4L6G] ("In the past, ... fewer than 1 percent of applicants were disqualified on public[ ]charge grounds."). 
Department of Homeland Security (DHS) finalized a regulation, Inadmissibility on Public Charge Grounds (the "public charge rule" or "new rule"), that would expand the application of public charge inadmissibility in several ways, thus transforming the operation of public charge law and potentially excluding many more noncitizens from becoming lawful permanent residents (LPR). ${ }^{17}$

Under the new rule, a noncitizen's use of public benefits, including Medicaid, is a more significant (and more negatively weighted) factor in the public charge analysis. ${ }^{18}$ The effect of this change is to shift the focus of the public charge analysis from dependence on government support to any use of public benefits, "even in a relatively small amount or for a relatively short duration." 19

The new rule was scheduled to go into effect in October 2019 but, at the time of publication of this Essay, it was enforced for only a short period in the spring of 2020. This is because, immediately after the new rule was finalized, a group of states and advocates for noncitizens filed lawsuits challenging it on several grounds. ${ }^{20}$ They succeeded in obtaining preliminary injunctions temporarily halting implementation of the new rule. ${ }^{21}$ However,

${ }^{17}$ Inadmissibility on Public Charge Grounds, 84 Fed. Reg. 41,292 (Aug. 14, 2019) (to be codified at 8 C.F.R. pts. 103, 212, 213, 214, 245, 248).

18 Id. at $41,298-99$.

19 Id. at 41,354 (quoting Inadmissibility on Public Charge Grounds, 83 Fed. Reg. 51,114, 51,164 (proposed Oct. 10, 2018) (to be codified at 8 C.F.R. pt. 103, 212, 213, 214, 245, 248)); id. at 41,354-55 (defending its interpretation).

${ }^{20}$ See, e.g., Complaint at 19-21, City of San Francisco v. U.S. Citizenship \& Immigr. Servs., 408 F. Supp. 3d 1057 (N.D. Cal. 2019) (No. 3:19-cv-4717) (claiming the new rule constitutes an unlawful agency action under the Administrative Procedure Act because it is "not in accordance with law" and because it is "arbitrary, capricious and an abuse of discretion"); Complaint at 153-63, Washington v. U.S. Dep't of Homeland Sec., 408 F. Supp. 3d 1191 (E.D. Wash. 2019) (No. 4:19-cv-05210) (alleging the same Administrative Procedure Act violations, an additional Ultra Vires violation under the Act, and a denial of the constitutional right to equal protection); see also Wendy E. Parmet, Supreme Court Allows Public Charge Rule To Take Effect While Appeals Continue, Health AfFs. Blog (Feb. 3, 2020), https://www.healthaffairs.org/do/10.1377/hblog20200131.845894/full/ [https://perma.cc/89BE-9S6Y? type=image] (summarizing the various plaintiffs' arguments that the new rule "exceeded DHS' statutory authority, violated the Administrative Procedures Act, discriminated on the basis of disability, and offended the Equal Protection Clause of the Constitution").

${ }^{21}$ See Washington v. U.S. Dep't of Homeland Sec., 408 F. Supp. 3d 1191, 1224 (E.D. Wash. 2019) (order granting preliminary injunction); City of San Francisco v. U.S. Citizenship \& Immigr. Servs., 408 F. Supp. 3d 1057, 1130 (N.D. Cal. 2019) (order granting preliminary injunction); CASA de Md., Inc. v. Trump, No. 8:19-cv-02715-PWG, slip op. at 2 (D. Md. Oct. 14, 2019) (order granting preliminary injunction); Cook Cnty. v. McAleenan, 417 F. Supp. 3d 1008, 1031 (N.D. Ill. 2019) (order granting preliminary injunction); New York v. U.S. Dep't of Homeland Sec., 408 F. Supp. 3d 334, 353 (S.D.N.Y. 2019) (order granting preliminary injunction), aff'd as modified, Nos. 19-3591, 19-3595, $2020 \mathrm{WL}$ 4457951 (2d Cir. Aug. 4, 2020) (upholding the prior injunction but limiting its applicability to New York, Connecticut, and Vermont); Make the Rd. N.Y. v. Cuccinelli, 419 F. Supp. 3d 647, 668 (S.D.NY. 2019) 
in January 2020, the U.S. Supreme Court stayed the injunction, allowing DHS to implement the new rule while the litigation proceeds. ${ }^{22}$ DHS began enforcing the new rule on February 24, 2020, ${ }^{23}$ but was blocked anew on July 29,2020 , when a federal district judge granted a motion for a nationwide preliminary injunction preventing its implementation during the COVID-19 emergency. ${ }^{24}$ Litigation challenging the new rule is ongoing and future court orders could permit DHS to implement the new rule once again.

Noncitizens who were subject to the new rule during the months it was implemented had to make the difficult choice of disenrolling from certain health-supporting public benefits or remaining enrolled but risking denial of future applications for LPR status. ${ }^{25}$ Noncitizens who may be subject to the new rule in the future face the same quandary. But this is not the major effect of DHS's dramatic reformulation of public charge. Rather, the new rule sows confusion among noncitizens about the relationship between use of public benefits and eligibility for immigration benefits. ${ }^{26}$ Many noncitizens, even those who are not subject to public charge, have declined to enroll in public benefits that provide health coverage or supplement budgets for food, housing, and other essentials out of fear of negative immigration consequences. $^{27}$ The Trump Administration's proposed and enacted immigration policies can thus be blamed for a marked decrease in noncitizen enrollment in public benefits, even those that are not considered in the public charge analysis, like Emergency Medicaid. ${ }^{28}$

To complicate matters, implementation of the public charge rule coincided with the Administration's first significant actions to prepare for an outbreak of COVID-19 in the United States. ${ }^{29}$ Based on their understanding

(order granting preliminary injunction), aff'd as modified sub nom. New York v. U.S. Dep't of Homeland Sec., Nos. 19-3591, 19-3595, 2020 WL 4457951 (2d Cir. Aug. 4, 2020) (upholding the prior injunction but limiting its applicability to New York, Connecticut, and Vermont).

22 U.S. Dep't of Homeland Sec. v. New York, 140 S. Ct. 599, 600 (2020) (staying nationwide injunction except for in Illinois); Wolf v. Cook Cnty., 140 S. Ct. 681, 681 (2020) (staying statewide Illinois injunction).

${ }^{23}$ See DHS Implements Inadmissibility on Public Charge Grounds Final Rule, U.S. DEP'T Homeland SEC. (Feb. 24, 2020), https://www.dhs.gov/news/2020/02/24/dhs-implementsinadmissibility-public-charge-grounds-final-rule [https://perma.cc/TY87-2GHC].

${ }^{24}$ New York v. U.S. Dep't of Homeland Sec., Nos. 1:19-cv-07777, 1:19-cv-07993, 2020 WL 4347264 (S.D.N.Y. July 29, 2020).

${ }^{25}$ See Inadmissibility on Public Charge Grounds, 84 Fed. Reg. 41,312-13 (Aug. 14, 2019) (to be codified at 8 C.F.R. pts. 103, 212, 213, 214, 245, 248).

26 See supra notes $62,74-75$ and accompanying text.

27 See supra notes 59-63, 74-76 and accompanying text.

28 See supra note 67 and accompanying text

29 On February 24, 2020, the administration requested emergency funding from Congress to support the COVID-19 response. The next day, the Centers for Disease Control and Prevention officially warned 
of the public charge rule, noncitizens who hope to gain LPR status - the first step on the path to becoming a U.S. citizen - may be unwilling to seek treatment or testing for COVID-19 or to access public benefits in order to comply with stay-at-home guidance. ${ }^{30}$ The new rule leaves these noncitizens and the people with whom they live, including U.S. citizens, disproportionately vulnerable to suffering and possibly dying from untreated COVID-19. It also leaves them at heightened risk of food insecurity, homelessness, and other maladies linked with a sudden loss of income and increased exposure to infectious disease. The pandemic thus exposes the folly of the new rule by revealing its major effect: chilling noncitizens' use of public benefits that would support their health and wellbeing.

In Part I, this Essay describes how DHS's new rule shifts the focus of the public charge analysis from primary dependency on government support to any reliance on public benefits, however minimal or short-term. Part II examines how justifiable fear and confusion over the new rule, combined with the potentially severe ramifications of being deemed a public charge, has chilled noncitizens from accessing Medicaid and other public benefits. This chilling effect has persisted during the COVID-19 pandemic, even for public benefits that are excluded from the public charge analysis and among noncitizens who are not themselves subject to the rule. Part III then discusses the impact this rule will have on public health during the pandemic. Finally, Part IV dissects the steps that DHS had taken to temporarily ameliorate the negative consequences of the rule during its five month period of implementation and explains how they fall short.

\section{The New Public CHARge Rule}

Under the prior interpretation of the public charge statute, applicants for LPR status were denied admission if they were likely to become "primarily dependent on the government for subsistence." ${ }^{31}$ In effect, a public charge

\footnotetext{
of an inevitable, widespread outbreak of the virus in the United States. The day after that, Vice President Pence was appointed to lead the White House Coronavirus Task Force. Philip A. Wallach \& Justus Myers, The Federal Government's Coronavirus Response-Public Health Timeline, BRoOKInGS (Mar. 31, 2020), https://www.brookings.edu/research/the-federal-governments-coronavirus-actions-and-failurestimeline-and-themes/ [https://perma.cc/ZYW6-7C2Q].

30 See Kathryn Pitkin DeRose, Opinion, The Public Charge Rule's Likely Hazard to Our Nation's Health During COVID-19, THE HILL (Apr. 3, 2020, 8:00 PM), https://thehill.com/opinion/whitehouse/491080-the-public-charge-rules-likely-hazard-to-our-nations-health-during-covid

[https://perma.cc/H4CV-A8J8] (“[A]n Urban Institute survey of non-elderly adults in immigrant families in December 2018, while the rule had not been finalized nor implemented, found that one in seven elected to not participate in a noncash government benefit program in 2018 because they feared hurting their or their families' green card application.”).

31 Field Guidance on Deportability and Inadmissibility on Public Charge Grounds, 64 Fed. Reg. 28,689, 28,689 (Mar. 26, 1999) (emphasis added).
} 
was a person who was likely to become totally dependent on the government for support, as demonstrated by the receipt of public benefits that provide cash assistance or institutionalization for long-term care. ${ }^{32}$ Under this policy, fewer than $1 \%$ of applicants for admission were denied..$^{33}$

The new rule redefines public charge to mean "an alien who receives one or more designated public benefits for more than 12 months in the aggregate within any 36-month period." ${ }^{34}$ The new rule also expands the types of public benefits that would be considered in determining whether an applicant for LPR status is a public charge. ${ }^{35}$ For the first time, enrollment in Medicaid, the Supplemental Nutrition Assistance Program (SNAP, or "Food Stamps"), and subsidized housing programs would be considered a negative factor in the public charge analysis. ${ }^{36}$

As one of us has detailed elsewhere, public health considerations were an influential factor in the development of public charge policy for more than a century. ${ }^{37}$ The prior policy, as described in a 1999 Immigration and Naturalization Service (INS) Field Guidance, states that the agency's interpretation of the public charge statute was intended "to reduce the negative public health consequences generated by the existing confusion and to provide aliens with better guidance as to the types of public benefits that will and will not be considered in public charge determinations." ${ }^{38}$ The INS was aware that noncitizens were forgoing or disenrolling from public benefits based on a fear of being deemed a public charge. ${ }^{39}$ Specifically, the INS was concerned that noncitizens would be unable to access "emergency and other medical assistance, children's immunizations, and basic nutrition programs, as well as the treatment of communicable diseases." 40

The new rule abandons this public health rationale. First, DHS, the successor agency to the INS, declined to respond to detailed analyses submitted in the notice and comment process describing the potential impact

\footnotetext{
32 Id.

33 Liptak, supra note 16.

34 Inadmissibility on Public Charge Grounds, 84 Fed. Reg. 41,292, 41,295 (Aug. 14, 2019) (to be codified at 8 C.F.R. pts. 103, 212, 213, 214, 245, 248).

35 Id.

${ }^{36}$ Id. Enrollment in Medicaid was considered under the prior public charge policy only when it provided institutionalization for long-term care. Id. at 41,379.

37 See Makhlouf, supra note 14, at 202-08.

38 Field Guidance on Deportability and Inadmissibility on Public Charge Grounds, 64 Fed. Reg. 28,689, 28,689 (Mar. 26, 1999).

39 Inadmissibility and Deportability on Public Charge Grounds, 64 Fed. Reg. 28,676, 28,676 (proposed May 26, 1999) (to be codified at 8 C.F.R. pts. 212 and 237).

${ }^{40} I d$.
} 
of the new rule's chilling effect. ${ }^{41}$ Second, the agency departed from a longstanding interpretation of the statute that balances public health considerations with the goal of supporting the long-term self-sufficiency of noncitizen members of the community who seek to reside in the United States permanently. ${ }^{42}$ DHS acknowledges and blatantly disregards the negative health-related consequences of the new rule's chilling effect. ${ }^{43}$

In its notice of proposed rulemaking, DHS describes the policy's potential to cause harm to individual and public health, health care system efficiency, and the economy. It notes that families with noncitizens that disenroll from or forego enrollment in public benefits programs may experience " $[\mathrm{w}]$ orse health outcomes, including increased prevalence of obesity and malnutrition, especially for pregnant or breastfeeding women, infants, or children." ${ }^{44}$ In addition, lack of health coverage and tightened household budgets due to loss of other public benefits may prevent patients from taking their medication as prescribed or at all. ${ }^{45}$ An acutely relevant public health risk posed by the new rule and acknowledged by DHS is "[i]ncreased prevalence of communicable diseases." ${ }^{46}$ Regarding harms to health care system efficiency, households without health coverage or the resources to pay for a doctors' visit out-of-pocket are more likely to seek care in an emergency room (the most expensive health care venue) for issues that are more appropriately and inexpensively treated by primary health care providers. ${ }^{47}$ Alternatively, patients may delay seeking care until health problems become emergent, thus increasing the unnecessary use of emergent care. ${ }^{48}$ At the macroeconomic level, DHS recognizes that the new rule could lead to "[i]ncreased rates of poverty and housing instability; and... [r]educed productivity and educational attainment." ${ }^{49}$ Such consequences cannot be summarily dismissed in immigration policymaking that is well motivated.

\footnotetext{
41 Inadmissibility on Public Charge Grounds, 84 Fed. Reg. at 41,313 (explaining that "DHS finds it difficult to predict the rule's disenrollment impacts with respect to people who are not regulated by this rule, such as people who erroneously believe themselves to be affected. ... DHS will not alter this rule to account for ... unwarranted choices" "to disenroll from a public benefit program or forego enrollment in response to this rule when such individuals are not subject to this rule").

42 Makhlouf, supra note 14, at 202-08.

43 Inadmissibility on Public Charge Grounds, 83 Fed. Reg. 51,114, 51,270 (proposed Oct. 10, 2018) (to be codified at 8 C.F.R. pts. 103, 212, 213, 214, 245, 248)).

${ }^{44}$ Id.

${ }^{45}$ See id.

46 Id.

47 See id.

48 See id.

${ }^{49} \mathrm{Id}$.
} 
Despite acknowledging these consequences, DHS did not attempt to quantify them or weigh them against the perceived benefits of the rule. ${ }^{50}$ This disregard for the negative public health consequences of public charge policy represents a dramatic shift in the way that the public charge statute has been interpreted. ${ }^{51}$ Of particular relevance, noncitizen access to testing and treatment for communicable diseases was previously considered a vital public health concern that the INS intended to promote through public charge policy. ${ }^{52}$

When policymakers have incorporated public health concerns into public charge policy, it is not merely - or even primarily - for humanitarian reasons..$^{53}$ Rather, it helps to accomplish one of the main goals of the public charge statute, which is to foster long-term self-sufficiency among noncitizens living in the United States. ${ }^{54}$ Under the old policy, noncitizens were not penalized for use of noncash public benefits such as Medicaid, SNAP, and housing if they became ill, disabled, or otherwise unable to earn adequate income because it was understood that such benefits would "sustain and improve their ability to remain self-sufficient." 55 The new rule, on the other hand, ignores this history ${ }^{56}$ Rather, it is part of a larger agenda by the Trump Administration to (1) slash enrollments in public benefits in service of a flawed, ahistorical conception of self-sufficiency, ${ }^{57}$ and (2) enact punitive immigration policy designed to discourage noncitizens from entering or remaining in the United States. ${ }^{58}$

\section{CHILLING EFFECTS}

Long before the new rule was proposed, drafts were leaked to the media, instilling widespread fear of enrolling in public benefits among

\footnotetext{
50 See Inadmissibility on Public Charge Grounds, 84 Fed. Reg. 41,292, 41,489 (Aug. 14, 2019) (to be codified at 8 C.F.R. pts. 103, 212, 213, 214, 245, 248).

51 Makhlouf, supra note 14, at 190-93.

52 See Inadmissibility and Deportability on Public Charge Grounds, 64 Fed Reg. 28,676, 28,676 (proposed May 26, 1999) (to be codified at 8 C.F.R. pts. 212 and 237).

53 See Makhlouf, supra note 14, at 184.

54 See id.

55 Id. at 188-89 (quoting Inadmissibility and Deportability on Public Charge Grounds, 64 Fed. Reg. at 28,678 ).

56 Inadmissibility on Public Charge Grounds, 84 Fed. Reg. 41,292, 41,314 (Aug. 14, 2019) (to be codified at 8 C.F.R. pts. 103, 212, 213, 214, 245, 248) (acknowledging that the agency "does not believe that Congress intended for DHS to administer [the public charge law] in a manner that fails to account for aliens' receipt of food, medical, and housing benefits so as to help aliens become self-sufficient. DHS believes that it will ultimately strengthen public safety, health, and nutrition through this rule by denying admission or adjustment of status to aliens who are not likely to be self-sufficient").

57 Makhlouf, supra note 14, at 204.

58 See K-Sue Park, Self-Deportation Nation, 132 HARV. L. ReV. 1878, 1920-32 (2019).
} 
noncitizens. ${ }^{59}$ Beginning in 2018, in anticipation of a change in public charge policy, immigration advocates and the media observed that noncitizens were disenrolling from, or forgoing enrollment in, public benefits out of fear of negative immigration consequences. ${ }^{60}$ The Trump Administration's antiimmigrant rhetoric and crackdown on immigration enforcement has exacerbated this "chilling effect" on noncitizen enrollment in public benefits. ${ }^{61}$ Much of the reasonable confusion about the new rule has to do with who is subject to a public charge determination, how use of public benefits is considered in the analysis, and which public benefits are considered. ${ }^{62}$

This confusion about the scope of the public charge rule means that noncitizens who are not subject to the rule, such as LPRs and naturalized citizens, will be, or already have been, deterred from enrolling in public benefits based on a fear of negative immigration consequences. ${ }^{63}$ Moreover, confusion about how use of public benefits factors into the public charge analysis will undoubtedly cause some applicants for LPR status to avoid health-promoting public benefits even if, based on a totality of circumstances analysis, they would not be considered a public charge. This is because, under the new rule, immigration officers retain broad discretion to weigh an applicant's use of public benefits (a "heavily weighted negative factor") ${ }^{64}$ against various other factors such as age, health, family status, assets, and education, when assessing the likelihood that the applicant will become a

\footnotetext{
59 See Access to Health Care, Food, and Other Public Programs for Immigrant Families Under the Trump Administration, NAT'L IMMIGR. L. CTR., 1, 3 (Apr. 2, 2018), https://www.nilc.org/wpcontent/uploads/2018/02/talking-to-immigrants-about-public-programs-2018.pdf [https://perma.cc/3D FW-36U9] (documenting leaks of public charge policy).

60 See Hamutal Bernstein, Dulce Gonzalez, Michael Karpman \& Stephen Zuckerman, One in Seven Adults in Immigrant Families Reported Avoiding Public Benefit Programs in 2018, URB. INST. (May 2019), https://www.urban.org/sites/default/files/publication/100270/one_in_seven_adults_in_immigrant _families_reported_avoiding_publi_7.pdf [https://perma.cc/36JQ-Z44K]; Khushbu Shah, Alarmist $\bar{R}$ eporting Turns Immigrants Away from Social Services, Officials Say, COLUM. JouRnALISM REV. (Nov. 28, 2018), https://www.cjr.org/covering_the_health_care_fight/wic-immigrants.php [https://perma.cc/ B4ZB-GQKY]

${ }^{61}$ Makhlouf, supra note 14, at 207.

62 Tanya Broder, Avideh Moussavian \& Jonathan Blazer, Overview of Immigrant Eligibility for Federal Programs, NAT'L IMMIGR. L. CTR. 1 (2015), https://www.nilc.org/wp-content/uploads/2015 /12/overview-immeligfedprograms-2015-12-09.pdf [https://perma.cc/HF5B-JAEP].

${ }^{63}$ See, e.g., Jeanne Batalova, Michael Fix \& Mark Greenberg, Chilling Effects: The Expected Public Charge Rule and Its Impact on Legal Immigrant Families' Public Benefits Use, MIGRATION POL'Y INST. 29-31 (2018), https://www.migrationpolicy.org/research/chilling-effects-expected-public-charge-ruleimpact-legal-immigrant-families [https://perma.cc/WY3T-N5UB].

64 Inadmissibility on Public Charge Grounds, 84 Fed. Reg. 41,292-93, 41,298-99 (Aug. 14, 2019) (to be codified at 8 C.F.R. pts. 103, 212, 213, 214, 245, 248).
} 
public charge in the future. ${ }^{65}$ Even if applicants believe that their positive factors should outweigh any use of public benefits in a public charge analysis, it is not possible to predict with certainty what the immigration officer adjudicating the application will decide. ${ }^{66}$ This uncertainty leads noncitizen applicants to "play it safe" by avoiding enrolling in public benefits altogether. Finally, the chilling effect extends to public benefits that are not considered in the public charge analysis at all, such as Emergency Medicaid, Medicaid for pregnant women and children under the age of twenty-one, the Special Supplemental Nutrition Program for Women, Infants, and Children (WIC), and the Children's Health Insurance Program (CHIP). ${ }^{67}$

The chilling effect of changes to laws relating to noncitizen use of public benefits were well documented following the passage of the Personal Responsibility and Work Opportunity Reconciliation Act of 1996, which dramatically restricted noncitizen eligibility for federally funded public benefits. ${ }^{68}$ Researchers found that the chilling effect was responsible for reducing noncitizen enrollment in various public benefit programs by $17 \%$ to $78 \%{ }^{69}$ DHS acknowledged that the new rule has the potential to chill a broad swath of noncitizens from accessing public benefits. ${ }^{70}$

\footnotetext{
658 U.S.C. $\$ 1182(\mathrm{a})(4)(B)$; see also 84 Fed. Reg. at 41,295 (describing the operation of the public charge analysis as "based on the totality of the circumstances").

${ }^{66}$ See, e.g., Public Charge, Immigrant Legal ReS. CTR., https://www.ilrc.org/public-charge [https://perma.cc/SHH8-P4Y5] ("It is not clear how an immigration officer should decide a case that has a heavily weighted factor or, for instance, has both heavily weighted negative and positive factors, as no one factor should be dispositive.").

${ }^{67}$ See Public Charge Fact Sheet, U.S. CITIZENSHIP \& IMMIGR. SERVS., https://www.uscis.gov/news/ fact-sheets/public-charge-fact-sheet [https://perma.cc/3XJA-SPNQ].

68 Pub. L. No. 104-193, 110 Stat. 2105 (Aug. 22, 1996) (codified as amended in scattered sections of 42 U.S.C. and 8 U.S.C.).

${ }^{69}$ See Leighton Ku, Jessica Sharac, Rachel Gunsalus, Peter Shin \& Sara Rosenbaum, How Could the Public Charge Proposed Rule Affect Community Health Centers?, 55 GEIGER GIBSON/RCHN CMTY. HEALTh Found. RSCH. COLlabORATIVE, POL'Y IsSUE BRIEF 1, 4 (2018), https://publichealth.gwu.edu/ sites/default/files/downloads/GGRCHN/Public\%20Charge\%20Brief.pdf [https://perma.cc/WQ4TWH8G].

${ }^{70}$ Inadmissibility on Public Charge Grounds, 83 Fed. Reg. 51,114, 51,266 (proposed Oct. 10, 2018) (to be codified at 8 C.F.R. pts. 103, 212, 213, 214, 245, 248) (acknowledging, in the proposed rule, the enrollment reductions in public benefit programs after the passage of PRWORA and the potential of the proposed rule to have a similar effect).
} 
Prior to the pandemic, evidence of the new rule's chilling effect on noncitizen behavior was mounting. ${ }^{71}$ The chilling effect has persisted, ${ }^{72}$ as described by health care providers, lawyers, community organizations, state and local officials, and academics in support of legal requests to halt the implementation of the new rule during the pandemic. ${ }^{73}$ For example, multiple community organizations and health care providers across the country have reported that patients with symptoms of COVID-19 are afraid of seeking testing and treatment based on concerns about the new rule. ${ }^{74}$ They confirm that the chilling effect has influenced the behavior of noncitizens who are not directly subject to the rule, and that "substantial fear and confusion, along with the complicated nature of benefits programs, have led immigrants and their families to avoid state-funded health insurance programs, reduce their use of medical services, and forbear from using other public benefits not covered by the Rule." ${ }^{75}$ Evidence of the chilling effect's irreparable harm was a critical factor in U.S. District Judge George B. Daniels's most recent ruling halting implementation of the new rule nationwide. ${ }^{76}$

The Migration Policy Institute (MPI) estimated that over 10 million noncitizens, which is $47 \%$ of the noncitizen population in the United States, would disenroll from, or forgo enrollment in, public benefits because of the chilling effects of the changes to public charge policy. ${ }^{77}$ These noncitizens

71 See Trump's Public Charge Regulation Is Hurting Immigrant Families Now, ProteCting IMMIGRANT FAMILIES 2 (2020), https://protectingimmigrantfamilies.org/wp-content/uploads/2020/04/ DocumentingHarm-update-2020-04-27.pdf [https://perma.cc/9BJQ-5FSY] (describing, among others, the case of a mother who disenrolled her children from SNAP and Medicaid out of fear that their use of public benefits would negatively impact her own ability to obtain lawful permanent resident status).

72 See Hamutal Bernstein, Michael Karpman, Dulce Gonzalez \& Stephen Zuckerman, Immigrant Families Hit Hard by the Pandemic May Be Afraid to Receive the Help They Need, URB. InST. (May 19, 2020), https://www.urban.org/urban-wire/immigrant-families-hit-hard-pandemic-may-be-afraid-receivehelp-they-need [https://perma.cc/TW2F-FZZH].

73 Memorandum of Law in Support of Plaintiffs' Motion for Preliminary Injunction \& Stay or Temporary Restraining Order Pending National Emergency at 9-10, 17-18, New York v. U.S. Dep't of Homeland Sec., 2020 WL 4347264 (S.D.N.Y. Apr. 28, 2020) (Nos. 1:19-cv-07777, 1:19-cv-07993); Motion by Government Plaintiffs to Temporarily Lift or Modify the Court's Stay of the Orders Issued by the United States District Court for the Southern District of New York at 8-13, U.S. Dep't of Homeland Sec. v. New York, 140 S. Ct. 2709 (2020) (No. 19A785).

${ }^{74}$ Memorandum of Law in Support of Plaintiffs' Motion for Preliminary Injunction \& Stay or Temporary Restraining Order Pending National Emergency, supra note 73, at 9-10.

${ }^{75} \mathrm{Id}$. at 10.

76 New York v. U.S. Dep't of Homeland Sec., Nos. 1:19-cv-07993, 1:19-cv-0777, 2020 WL 4347264, at *10-11 (S.D.N.Y. July 29, 2020). The Court explicitly recognized the new rule's harm to noncitizens who mistakenly believe that it applies to them or to benefits that are excluded from considerations, stating that "the Supreme Court has recognized injury where the plaintiff's harms are based on the 'predictable effect of Government action on the decisions of third parties,' even if such decisions are "motivated by unfounded fears." Id. at *24 (quoting Dep't of Commerce v. New York, 139 S. Ct. 2551, 2566 (2019)).

77 Batalova, Fix \& Greenberg, supra note 63, at 2-3. 
reside with 12 million U.S. citizen family members, including about 8 million citizen children. ${ }^{78}$ Forgone enrollment in public benefits by an individual affects the budget of the entire household. Therefore, the families of noncitizens chilled from accessing public benefits suffer alongside them.

\section{Public Health CONSEQUenCeS}

The new rule's disregard of public health consequences weakens our fight against the COVID-19 pandemic by discouraging noncitizens from accessing (1) health care for treatment of COVID-19 symptoms, and (2) public benefits that enable compliance with social distancing.

In disincentivizing noncitizens from enrolling in public benefits like Medicaid, the new rule negatively impacts public health by reducing noncitizen access to health care. It is estimated that 13.5 million enrollees in Medicaid or CHIP are noncitizens or live in a household with noncitizens. ${ }^{79}$ Reporters, health care providers, public officials, and nonprofit organizations serving noncitizens have documented that the chilling effect of the new rule persists during the pandemic. ${ }^{80}$ Noncitizens with COVID-19 symptoms who have declined to enroll in Medicaid and who do not have resources to pay out of pocket for health care will suffer disproportionately from untreated disease and will contribute to the uncontrolled spread of the virus. Any policy that discourages people who may have COVID-19 from accessing health care during the pandemic will weaken our fight against the spread of the virus.

Noncitizens who have lost income for pandemic-related reasons may fear enrolling in other public benefits as well, including those that would supplement their budgets for food, housing, utilities, medicine, personal protective equipment (PPE), cleaning supplies, internet, transportation, and other essentials. ${ }^{81}$ Low- and middle-income noncitizens are unlikely to have

\footnotetext{
78 Id. at 4. Manatt Health estimated the total potentially chilled population to be 25.9 million people with income below $250 \%$ of the federal poverty level, which includes noncitizens and their family members. Public Charge Proposed Rule: Potentially Chilled Population Data Dashboard, MANATT HEALTH (Oct. 11, 2018), https://www.manatt.com/insights/articles/2018/public-charge-rule-potentiallychilled-population [https://perma.cc/77BE-E5NJ].

79 Changes to "Public Charge" Inadmissibility Rule: Implications for Health and Health Coverage, KAISER FAM. FOUND. (Aug. 12, 2019), https://www.kff.org/disparities-policy/fact-sheet/public-chargepolicies-for-immigrants-implications-for-health-coverage/ [https://perma.cc/92WN-BPSB].

80 See New York v. U.S. Dep't of Homeland Sec., Nos. 1:19-cv-07777, 1:19-cv-07993, 2020 WL 4347264, at*10 (S.D.N.Y. July 29, 2020); Miriam Jordan, 'We're Petrified': Immigrants Afraid to Seek Medical Care for Coronavirus, N.Y. TIMES (Mar. 18, 2020), https:/www.nytimes.com/2020/03/18/us/ coronavirus-immigrants.html [https://perma.cc/JUS4-ZRTS].

81 See, e.g., David Velasquez, Jordan Kondo, Sarah Downer \& Emily Broad Leib, Maximizing Food Security for Unauthorized Immigrants During COVID-19, HeALTH AfFs. Blog (July 28, 2020),
} 
substantial savings to weather a prolonged period of unemployment or underemployment. ${ }^{82}$ Unlike U.S. citizens who can rely on public benefits for income support during the pandemic emergency, noncitizens who fear being deemed a public charge will face the difficult decision of making do with less or seeking employment with an essential business that will put them at increased risk of exposure to the virus. Consequences may be particularly severe for noncitizens who have underlying health conditions that put them at higher risk for severe illness from COVID-19 but who cannot afford to leave their jobs.

Noting that the long-term sequelae of infection with COVID-19 may be serious, particularly for high-risk individuals, it is obvious that the new rule is not calculated to promote long-term self-sufficiency among noncitizens..$^{83}$ Noncitizens who are discouraged from accessing public benefits to supplement their housing budgets may suffer from housing instability. If they lose housing, they may be forced to move in with another family or go to a homeless shelter - both of which will make it more difficult to practice social distancing and will increase their exposure to the virus. Similarly, inability to pay a utility bill can lead to a shutoff. Although some state and municipal authorities have suspended utility disconnections by government order for some period during the pandemic, shutoff protections are not available or uniform across the nation. ${ }^{84}$ If a household's water service is

https://www.healthaffairs.org/do/10.1377/hblog20200724.40740/full/ [https://perma.cc/L8P2-2QMZ] (discussing the public charge rule as a barrier to SNAP enrollment for noncitizens, which exacerbates food insecurity); Hamutal Bernstein, Dulce Gonzalez, Michael Karpman \& Stephen Zuckerman, Amid Confusion Over the Public Charge Rule, Immigrant Families Continued Avoiding Public Benefits in 2019, URB. INST. 2 (May 2020), https://www.urban.org/sites/default/files/publication/102221/amidconfusion-over-the-public-charge-rule-immigrant-families-continued-avoiding-public-benefits-in-

2019_3.pdf [https://perma.cc/627H-7589] (discussing the chilling effects of the new public charge rule on noncitizen enrollment in public benefits generally, including SNAP, housing subsidies, WIC, and free or reduced-price school lunches).

82 See Dulce Gonzalez, Michael Karpman, Genevieve M. Kenney \& Stephen Zuckerman, Hispanic Adults in Families with Noncitizens Disproportionately Feel the Economic Fallout from COVID-19, URB. INST. 3 (May 2020), https://www.urban.org/research/publication/hispanic-adults-familiesnoncitizens-disproportionately-feel-economic-fallout-covid-19/view/full report [https://perma.cc/H3NN-4Y4F] (stating that "[o]ver a third of Hispanic adults in families with noncitizens ... used up all or most of their family's savings" because of loss of work-related income due to the COVID-19 pandemic).

83 A. Pawlowski, What Are the Long-Term Health Consequences of COVID-19?, TODAY (Apr. 16, 2020, 7:19 AM), https://www.today.com/health/coronavirus-long-term-health-covid-19-impact-lungsheart-kidneys-t178770 [https://perma.cc/QE8J-8ZDP] (describing probable long-term impacts on the lungs, heart, kidneys, brain, and mental health).

${ }^{84}$ Press Release, Carper Releases Staff Analysis of State Efforts to Ensure Continued Utility Services for Americans Facing Economic Hardship, U.S. Senate Comm. on Env't \& Pub. Works, (Apr. 29, 2020), https://www.epw.senate.gov/public/index.cfm/press-releases-democratic?ID=F588E20E-7EE3-4075- 
disconnected, it is harder to comply with recommendations about handwashing (the best defense against contracting the virus) ${ }^{85}$ and regularly cleaning and disinfecting high-touch surfaces. ${ }^{86}$ It should come as no surprise that the communities with the highest rates of COVID-19 infections are among those with the highest pre-pandemic rates of water service disconnections for nonpayment of bills. ${ }^{87}$ Additionally, heating utility shutoffs are linked with suppression of the immune system, which would make the entire household more susceptible to illness, including COVID$19 .{ }^{88}$

Food insecurity has also been linked with "fatigue and reduced immune response, which increase the risk of contracting communicable diseases." ${ }_{89}$ Noncitizens who are discouraged from accessing SNAP or who disenroll from SNAP due to the new rule may need to rely on food pantries in order to have enough to eat. This new demand among noncitizens, as well as the many citizens who are accessing food pantries for the first time due to the pandemic, has exhausted these resources in parts of the country that have sustained the worst economic damage. ${ }^{90}$

And the new rule does not only affect noncitizens. Household members of noncitizens who are experiencing symptoms of COVID-19 will likely find it harder to manage their illness if they are chilled from accessing public benefits for which they are eligible. For example, mixed-status households, meaning those with both citizen and noncitizen members, that decline to enroll in SNAP are more likely to be food-insecure. ${ }^{91}$ Not only are children

AFEA-6076155688FC [https://perma.cc/M6B5-DFN7] [hereinafter Carper Releases Staff] (noting that orders by state utility regulators do not always apply to municipal utilities, which provide water service to an estimated $82 \%$ of Americans, expiration dates of shutoff protections vary, and not all government actions prevent all utilities from shutoff).

${ }^{85}$ Protect Yourself, CTRS. FOR DiSEASE CONTROL \& PREVENTION, https://www.cdc.gov/coronavirus /2019-ncov/prevent-getting-sick/prevention.html [https://perma.cc/LVW8-Z2WS].

${ }^{86}$ Carper Releases Staff, supra note 84 (describing the relationship between maintenance of residential water service and the ability to wash potentially contaminated surfaces).

87 Id.

88 James Krieger \& Donna L. Higgins, Housing and Health: Time Again for Public Health Action, 92 AM. J. PUB. HEALTH 758, 758 (2002).

${ }^{89}$ Caroline G. Dunn, Erica Kenney, Sheila E. Fleischhacker \& Sara N. Bleich, Feeding Low-Income Children During the Covid-19 Pandemic, 382 NEw ENG. J. MED. e40(1), e40(1) (2020).

90 See Paul Morello, COVID-19 Means a 'New Normal', FeEding Am. (May 4, 2020), https://www.feedingamerica.org/hunger-blog/covid-19-means-new-normal [https://perma.cc/4M5BZYLQ]; Nicholas Kulish, 'Never Seen Anything Like It': Cars Line Up for Miles at Food Banks, N.Y. TIMES (May 6, 2020), https://www.nytimes.com/2020/04/08/business/economy/coronavirus-foodbanks.html [https://perma.cc/8RBS-CAVJ].

${ }^{91}$ See, e.g., Mariana Chilton, Maureen M. Black, Carol Berkowitz, Patrick H. Casey, John Cook, Diana Cutts, Ruth Rose Jacobs, Timothy Heeren, Stephanie Ettinger de Cuba, Sharon Coleman, Alan 
in such households more susceptible to illness, a suppressed immune response makes it harder for them to recover from any illnesses they contract. ${ }^{92}$ Similarly, unstable or unsafe housing (including lack of access to heat, electricity, and water) is associated with poor recovery from illness. ${ }^{93}$

Finally, the new rule compounds problems of scarce medical resources. ${ }^{94}$ If people diagnosed with COVID-19 are unable to manage their symptoms at home, they will ultimately seek care in a hospital where they will unnecessarily consume scarce health care resources.

The major effect of the new rule-discouraging noncitizens from accessing health care and public benefits that support health and wellbeing - will, in a pandemic, ultimately increase the uncontrolled spread of disease, putting more people at risk of developing COVID-19. It also impedes efforts to slow the spread of the pandemic, potentially straining and overwhelming the health care system. In short, implementation of the new rule risks drawing out the pandemic as well as the unprecedented policies to combat it, which have brought life as we know it to a halt.

Myers \& Deborah A. Frank, Food Insecurity and Risk of Poor Health Among US-Born Children of Immigrants, 99 AM. J. PUB. HEALth 556, 556 (2009) ("In comparison with households in which all members are US born, households with immigrants are at a highly elevated risk of household food insecurity."); Neeraj Kaushal, Jane Waldfogel \& Vanessa R. Wight, Food Insecurity and SNAP Participation in Mexican Immigrant Families: The Impact of the Outreach Initiative, 14 B.E. J. ECON. ANALYSIS \& POL'Y 203, 232 (2013) (finding that mixed-status Mexican families have a higher incidence of food security and are less likely to participate in SNAP, compared with all-citizen and all-noncitizen families).

92 See Lenzy Krehbiel-Burton, More than Hunger Pains: How Food Insecurity Impacts the Body, USC ANNENBERG CTR. FOR HEALTH JOURNALISM (Mar. 8, 2016), https://www.centerfor healthjournalism.org/fellowships/projects/more-hunger-pains-how-food-insecurity-impacts-body [https://perma.cc/PF32-6CXD].

93 See, e.g., James Hamblin, Why Some People Get Sicker than Others, ATLANTIC (Apr. 21, 2020), https://www.theatlantic.com/health/archive/2020/04/coronavirus-immune-response/610228/

[https://perma.cc/MDW3-L8NT] (describing how variation in immune responses based on social determinants of health, including housing, will determine who becomes sickest from COVID-19 as "[u]ltimately, people who are unable to take time off of work when sick —or who don't have a comfortable and quiet home, or who lack access to good food and clean air-are likely to bear the burden of severe disease").

94 See, e.g., Ezekiel J. Emanuel, Govind Persad, Ross Upshur, Beatriz Thome, Michael Parker, Aaron Glickman, Cathy Zhang, Connor Boyle, Maxwell Smith \& James P. Phillips, Fair Allocation of Scarce Medical Resources in the Time of Covid-19, 382 NEW ENG. J. MED. 2049, 2049-51 (2020) (describing shortages of N-95 masks in the United States, intensive care beds and ventilators in Italy, hospital beds in South Korea, and protective gear in the United Kingdom and predicting, in May 2020, that "unless the epidemic curve of infected individuals is flattened over a very long period of time[,] the Covid-19 pandemic is likely to cause a shortage of hospital beds, ICU beds, and ventilators [in the United States.]" as well as future shortages of "healthy respiratory therapists and trained critical care staff" and "[d]iagnostic, therapeutic, and preventive interventions"). 


\section{THE FOLLY, EXPOSED}

On March 13, 2020 - just eighteen days after the new rule was implemented-U.S. Citizenship and Immigration Services (USCIS), a subagency within DHS, issued an alert regarding a modification of the public charge determination process that is intended to encourage noncitizens with symptoms of COVID-19 to seek treatment. ${ }^{95}$ This guidance, which was posted to the USCIS website but was not otherwise codified, stated that testing and treatment relating to COVID-19 that was subsidized by Medicaid would not be considered in public charge inadmissibility determinations. ${ }^{96}$ Although this indicated a partial recognition by DHS of the negative public health consequences of the new rule, it fell short because it still potentially penalized noncitizens who enrolled in Medicaid during the pandemic. Medicaid provides full-scope health coverage that includes coverage for conditions that put people at high risk of severe illness from COVID-19, such as asthma, diabetes, and heart disease.$^{97}$ If a noncitizen with such a condition sought medical attention for COVID-19 symptoms, should they have declined treatment for their other condition in order to avoid implicating the new rule? U.S. District Judge Daniels identified the unworkability of the USCIS guidance in his July 2020 decision, noting, "[t]here is no box for applicants to check off that limits their use of Medicaid to COVID-19-related treatment." ${ }^{98}$ It is unreasonable to expect people in such a position to determine whether the treatment they are receiving is related to COVID-19,

\footnotetext{
95 Public Charge, U.S. CitIZENShIP \& IMMIgr. SERVs. (Mar. 27, 2020), https://www.uscis.gov/greencard/public-charge [https://perma.cc/DUT4-FSWY]; Practice Alert: COVID-19 and the Public Charge Rule, Am. IMMIGR. LAW. Ass'N, (June 15, 2020), https://www.aila.org/advo-media/aila-practice-pointers-and-alerts/practice-alert-covid-19-and-thepublic-charge-rule [https://perma.cc/2V8Z-P7N2] (stating that the USCIS alert was posted on March 13, 2020).

96 Public Charge, supra note 95 (explaining that "[t]o address the possibility that some aliens impacted by COVID-19 may be hesitant to seek necessary medical treatment or preventive services, USCIS will neither consider testing, treatment, nor preventive care (including vaccines, if a vaccine becomes available) related to COVID-19 as part of a public charge inadmissibility determination ... even if such treatment is provided or paid for by one or more public benefits, as defined in the rule (e.g., federally funded Medicaid)").

97 See Mandatory \& Optional Medicaid Benefits, MEDICAID.GOv, https://www.medicaid.gov/ medicaid/benefits/mandatory-optional-medicaid-benefits/index.html [https://perma.cc/2QVS-S3KX] (last visited Aug. 3, 2020) (listing the benefits that states are required to provide through Medicaid, including inpatient hospital services, outpatient hospital services, and physician services). In addition, all fifty states and the District of Columbia provide prescription drug coverage through Medicaid, even though it is an optional benefit. See Recent Medicaid Prescription Drug Laws and Strategies, NAT'L CONF. State Legislators (Aug. 8, 2018), https://www.ncsl.org/research/health/medicaidpharmaceutical-laws-and-policies.aspx\#: :text=All\%20fifty $\% 20$ States $\% 20$ and $\% 20$ the,the $\% 20$ Medicaid \%20Drug\%20Rebate\%20Program [https://perma.cc/Q3BU-E4HC].

98 New York v. U.S. Dep't of Homeland Sec., Nos. 1:19-cv-07777, 1:19-cv-07993, 2020 WL 4347264, at*11 (S.D.N.Y. July 29, 2020).
} 
or to direct their health care providers to stop treating conditions that USCIS may determine are "unrelated." The patient cannot control what a provider bills to Medicaid, and, as a result, may have reasonably declined to enroll in Medicaid during the pandemic.

The USCIS alert also fell short of addressing the negative health consequences of the public charge rule because it did not eliminate consideration of the other types of public benefits that subsidize the purchase of food, housing, and other essentials in the public charge analysis, even if such enrollment is on account of the pandemic and can promote good health in ways unrelated to medical care. ${ }^{99}$ Rather, the alert described a new process by which noncitizens who enrolled in public benefits for pandemic-related reasons could introduce evidence of those reasons for consideration by USCIS. ${ }^{100}$ The decision of how to weigh this evidence, like the public charge determination itself, was left to individual USCIS officers with virtually unlimited discretion. ${ }^{101}$ Judge Daniels recognized the inadequacy of USCIS's assurance that it would take pandemic-related reasons for enrolling in public benefits into account, stating: "Such a hollow promise provides little comfort. Simply relying on the compassion or sympathy of immigration officials is not rational, either in rulemaking or in informally attempting to amend those rules." 102

The coronavirus pandemic has made obvious the essential folly of the public charge rule: Discouraging noncitizens from accessing public benefits to support their health and well-being is, and always has been, unwise from a public health perspective. Working collectively to assure the conditions in which people can be healthy is important all the time - not only during a public health crisis. The pandemic merely magnifies the negative public health consequences of the new rule because it puts U.S. residents, citizens and noncitizens alike, at risk of developing COVID-19, a deadly disease

99 See Public Charge, supra note 95.

100 See id.

101 See id. ("To the extent relevant and credible, USCIS will take all [] evidence into consideration in the totality of the alien's circumstances."); Policy Manual Chapter 2-Public Charge Inadmissibility Ground, U.S. CITIZENSHIP \& IMMIGR. SERVS. ("An alien is inadmissible on the public charge ground if the officer is of the opinion that the alien is, at the time of admission or at the time of adjustment of status, 'likely at any time to become a public charge."') (emphasis added); Policy Manual Chapter 4-Prospective Determination Based on Totality of the Circumstances, U.S. CITIZENSHIP \& IMMIGR. SERVS. ("The U.S. government has long interpreted the phrase 'in the opinion of' as describing an assessment that is subjective and discretionary in nature. ... [T] the extent that each applicant's facts and circumstances are unique, officers' public charge inadmissibility determinations will vary.").

102 U.S. Dep't of Homeland Sec., 2020 WL 4347264, at *12. 
without a cure, vaccine, or even an approved therapeutic treatment. ${ }^{103}$ In this time of crisis and uncertainty, there is heightened awareness of the degree to which the health of individuals across the country and, indeed, around the world, is interconnected. Good policy must honor these ties of interdependence and reinforce the shared responsibility for stopping the spread of COVID-19. ${ }^{104}$

Judge Daniels's recent ruling halting implementation of the new public charge rule astutely recognizes how changed circumstances during the COVID-19 pandemic expose the folly of the Trump Administration's public charge policy. ${ }^{105}$ Notably, the opinion looks beyond the impracticality of implementing the new rule in the current national health emergency, questioning its enforceability during "future deadly plagues, earthquakes, hurricanes, tornadoes, floods, or other natural and manmade disasters that threaten the health and safety of citizens and immigrants alike, through no fault of their own." 106 It rejects a narrow conception of self-sufficiency, pinpointing the Trump Administration's failure to acknowledge that the health of citizens and noncitizens residing in the United States is interdependent. The Court relates this last point succinctly and memorably: "Protecting [noncitizens] is in their best interest and the interest of the public at large." 107

It remains to be seen whether this latest ruling in the ongoing litigation over the public charge rule will have any effect on noncitizens' decisions about enrollment. It is likely that many noncitizens will continue to forgo

103 See, e.g., Jonathan Corum, Sui-Lee Wee \& Carl Zimmer, Coronavirus Vaccine Tracker, N.Y. TIMES, https://www.nytimes.com/interactive/2020/science/coronavirus-vaccine-tracker.html [https://perma.cc/GHJ8-6Q4W] (updated regularly) (tracking the development of a coronavirus vaccine, which is currently being tested in clinical trials); COVID-19 Therapeutics Prioritized for Testing in Clinical Trials, NAT'L INSTS. HEALTH, https://www.nih.gov/research-training/medical-researchinitiatives/activ/covid-19-therapeutics-prioritized-testing-clinical-trials [https://perma.cc/JS7A-2ADW] (describing a public-private effort in the United States to evaluate therapeutic agents to aid COVID-19 treatment, which, at the time of publication, were in clinical trials); Jeff Craven, COVID-19 Therapeutics Tracker, REG. AFFS. PROF'LS SOC'Y (Oct. 2, 2020), https://www.raps.org/news-and-articles/newsarticles/2020/3/covid-19-therapeutics-tracker [https://perma.cc/HX7D-WAHM] (describing international effort to evaluate therapeutic agents to aid COVID-19 treatment).

104 The Secretary-General of the United Nations, António Guterres, captured this sentiment in a video address on March 13, 2020, stating, "[a] pandemic drives home the essential interconnectedness of our human family. Preventing the further spread of COVID-19 is a shared responsibility for us all." António Guterres, COVID-19: We Will Come Through this Together, United NATIONS (Mar. 13, 2020), https://www.un.org/en/coronavirus/covid-19-we-will-come-through-together [https://perma.cc/YNE2DC63].

105 U.S. Dep't of Homeland Sec., 2020 WL 4347264, at *13 ("All agree that the Rule should not [] be applied, as written, during this current pandemic.... The Rule has demonstrably failed the first real world test of its application.").

$106 \mathrm{Id}$. at $* 13$.

107 Id. at $* 11$. 
enrollment in public benefits due to chilling effects, the possibility that a subsequent court order will permit implementation of the new rule, and mistrust of the Administration. A noncitizen interviewed by the New York Times captured this sentiment saying: "We're petrified. . . . This president says one thing one day and does another the next." 108

Given the likelihood that the most recent ruling halting implementation of the new rule will fail to mitigate its negative public health consequences, DHS should, of its own accord, suspend implementation of the new rule retroactively to the date of implementation and until community transmission of COVID-19 is significantly reduced in the United States. The suspension should apply across the board, to all noncitizens subject to public charge and to all use of noncash public benefits. Only a clear statement from DHS suspending the operation of the public charge rule will persuade noncitizens to seek testing and treatment for COVID-19 and enroll in public benefits to support their health and well-being during this uncertain time. When the post-pandemic social and economic recovery is under way, DHS will be in a better position to make clear-headed and enduring policy on the appropriate consideration of noncitizen use of public benefits in immigration applications.

As the litigation over the legality of the new public charge rule makes its way through the courts, the federal judges hearing any future requests and appeals should include in their deliberation an analysis of the new rule's negative public health consequences. This is especially true now that the COVID-19 pandemic has revealed the folly of the Trump Administration's public charge policy.

\section{CONCLUSION}

On the cusp of what was believed to be the first COVID-19 death in the United States, ${ }^{109}$ the Trump Administration received permission from the U.S. Supreme Court to begin implementing its new public charge rule. ${ }^{110}$ DHS officials had ample evidence of the potentially devastating public

\footnotetext{
108 Jordan, supra note 80.

109 See Derrick Bryson Taylor, A Timeline of the Coronavirus Pandemic, N.Y. TIMES (Aug. 6, 2020), https://www.nytimes.com/article/coronavirus-timeline.html [https://perma.cc/YE5A-SL95] (noting that the United States reported "what was believed to be the first coronavirus death in the United States" on February 29, 2020, although it was later discovered that two people had died from COVID-19 in January).

110 U.S. Dep't of Homeland Sec. v. New York, 140 S. Ct. 599, slip op. at 2 (2020) (staying nationwide injunction except for in Illinois); Wolf v. Cook Cnty., 140 S. Ct. 681, 681 (2020) (staying statewide Illinois injunction)
} 
health impacts of the new rule, ${ }^{111}$ but it is unclear whether they weighed those harms against the purported benefits of enforcing the new immigration policy. ${ }^{12}$ An impending outbreak of infectious disease is the most obvious manifestation of the ways in which the health and well-being of all who live in the United States is interdependent. Nevertheless, it took the proclamation of a national emergency to persuade DHS to act in the interest of public health and modify application of the rule. ${ }^{113}$ And it took a court order in the midst of a raging pandemic - with no end in sight - to compel DHS to stop implementing the new rule altogether. ${ }^{114}$

The new public charge rule is one among many immigration laws and policies that have a primary or secondary effect of making life difficult for noncitizens. In immigration scholarship and politics, this is known as "selfdeportation" strategy. ${ }^{115}$ The idea is to make noncitizens' lives so unbearable that they are compelled to leave the country. ${ }^{116}$ In other words, "cruelty is the point." 117 Historically, this strategy appears in laws that make it difficult or impossible for noncitizens to access in-state tuition, student financial aid, and drivers' licenses; to work or rent living space; to call the police without fear of being questioned about one's immigration status; or to express one's cultural heritage by displaying foreign flags or speaking in languages other than English in schools and other public institutions. ${ }^{118}$ More recently, it appears as mass surveillance, arrest, and detention of noncitizens in sub-

111 See, e.g., Brief for Public Health, Health Policy, Medicine, and Nursing Deans, Chairs and Scholars et al. as Amici Curiae Supporting Plaintiffs at 1, Make the Rd. N.Y. v. Cuccinelli, 419 F. Supp. 3d 647 (S.D.N.Y. 2019) ( "In short, this Rule threatens a public health crisis on a national scale.").

112 See Public Charge Fact Sheet, supra note 67 (stating that the new public charge rule would be enforced beginning February 24, 2020); Inadmissibility on Public Charge Grounds, 83 Fed. Reg. 51,114, 51,270 (proposed Oct. 10, 2018) (to be codified at 8 C.F.R. pts. 103, 212, 213, 214, 245, 248).

113 See Proclamation No. 9994, 85 Fed. Reg. 15,337 (Mar. 13, 2020); Practice Alert: COVID-19 and the Public Charge Rule, supra note 95 (describing modification of public charge analysis for public benefits use relating to COVID-19).

114 New York v. U.S. Dep't of Homeland Sec., Nos. 1:19-cv-07993, 1:19-cv-07777, 2020 WL 4347264 (S.D.N.Y. July 29, 2020).

115 Park, supra note 58, at 1939 (describing the strategy as "targeting [noncitizens'] ability to keep their families together, access the protections of the legal system, move through public space without fear of public or private violence, and obtain shelter, employment, healthcare, and education").

116 See id. at 1882.

117 Julianne Hing, For Trump, Cruelty Is the Point, NATION (Mar. 15, 2018), https://www.thenation.com/article/archive/for-trump-cruelty-is-the-point/ [https://perma.cc/Z22BYS5A] (describing Trump administration immigration policies, including the new public charge rule, as "designed to maximize suffering").

118 See Park, supra note 58, at 1881 (summarizing state and local legislation introduced in the 2000s that embraced the self-deportation strategy). 
standard conditions; ${ }^{119}$ withholding federal funds from states that create "sanctuary" policies by refusing to cooperate with U.S. immigration authorities; ${ }^{120}$ and countless expressions of racial animus toward noncitizens. ${ }^{121}$

Immigration policies that attempt to make life miserable for noncitizens as a sort of "test" or "ordeal" are a poor way to ration scarce resources and promote the common good. ${ }^{122}$ They overlook the reality that personal and mass disasters, emergencies, injuries, illness, and disability can disrupt anyone's best-laid plans and cause them to become dependent on others. The ties of interdependence between U.S. citizens and noncitizens run much broader and deeper than susceptibility to the spread of infectious disease. ${ }^{123}$ Understanding this fact enables us to recognize the new public charge rule for what it is: one element of a larger agenda to crack down on immigration enforcement and reduce spending on anti-poverty programs. If the United States continues to underprioritize and underinvest in the health of any segment of society, it is destined to prolong the COVID-19 emergency and repeat its tragically inadequate response to the pandemic during the next national emergency.

119 See generally ACLU, JustiCE-FREE ZONES: U.S. IMMIGRATION DETENTION UNDER THE TRUMP ADMINISTRATION (2020), https://www.hrw.org/sites/default/files/supporting_resources/justice_free_ zones_immigrant_detention.pdf [https://perma.cc/X5W3-H3P5] (describing patterns of mistreatment and abuse at immigration detention centers under the Trump administration).

120 See Annie Correal, Trump Can Withhold Millions from 'Sanctuary' States, Court Rules, N.Y. TIMES (Feb. 26, 2020), https://www.nytimes.com/2020/02/26/nyregion/sanctuary-cities-funding.html [https://perma.cc/AEM4-Z7KN].

121 See Jayashri Srikantiah \& Shirin Sinnar, White Nationalism as Immigration Policy, 71 STAN. L. REV. ONLINE 197, 198-99 (2019) (recounting instances of Donald Trump's disparagement of nonwhite immigrants).

122 See Eisha Jain, The Interior Structure of Immigration Enforcement, 167 U. PENN. L. REV. 1463, 1490 (2019) (describing how expanded interior immigration enforcement that is designed to promote selfdeportation creates incentives for noncitizens to engage in socially undesirable or costly behaviors); Medha D. Makhlouf, Healthcare Sanctuaries 31-35 (2020) (unpublished manuscript) (on file with author) (discussing the collateral consequences of DHS policies that permit immigration surveillance at health care sites and through publicly funded health care programs).

123 See, e.g., Mercer Gary \& Nancy Berlinger, Interdependent Citizens: The Ethics of Care in Pandemic Recovery, 50 HASTINGS CTR. ReP. 56, 56 (2020) (noting that the COVID-19 pandemic has forced recognition of "interdependence as a necessary aspect of the human condition"). 